\title{
Snack Bar Catfish Bone Meal and Red Bean Flour For Malnourished Children: Nutritional Content and Sensory Properties
}

\author{
$1^{\text {st }}$ Yuli Hartati \\ Departemen of Nutrition \\ Politeknik Kesehatan Kemenkes Palembang \\ Palembang, Indonesia \\ yuli.hartati@poltekkespalembang
}

\author{
$2^{\text {nd }}$ M. Ridhoi \\ Departemen of Nutrition \\ Politeknik Kesehatan Kemenkes Palembang \\ Palembang, Indonesia \\ muhammadridhoi76336@gmail.com
}

Corresponding author: yuli.hartati@ poltekkespalembang

\begin{abstract}
Lack of Protein Energy is a nutritional problem that occurs throughout the world, especially in developing countries including Indonesia. One of strategy to overcome the problem of Lack of Protein Energy is to provide foods that are high in energy and high in protein such as snack bars. Food ingredients that can be used as basic ingredients to make snack bars include catfish, red beans and Moringa leaves. Catfish, kidney beans, and Moringa leaves contain high protein, suitable for use as a snack bar ingredient. This study aims to determine the effect of substitution of catfish meal, red bean flour, and Moringa leaf flour on the acceptability of snack bars for children with protein deficiency. This study used an experimental study with a completely randomized design (CRD) nonfactorial. The results showed that the selected snack bar was a snack bar with the formula F2 (10 grams of catfish flour, 90 grams of red bean flour, 3 grams of Moringa leaf flour) with an energy content of 466.41 Kcal, $17.02 \%$ protein, 22.81 fat. \%, $48.26 \%$ carbohydrates in every 100 grams of snack bars. There is an effect of substitution of catfish meal, red bean flour, and moringa leaves on the taste, color, aroma, and texture of the snack bar.
\end{abstract}

Keywords: snack bar, catfish, red beans, Moringa leaves, acceptance.

\section{INTRODUCTION}

Basic Health Research (RIKESDAS) in 2010, states that there are $21.5 \%$ of children aged 2-4 years with energy intake below the minimum requirement and $16 \%$ who consume protein below the minimum requirement[1]. In the 2018 Basic Health Research (RIKESDAS), it showed that the prevalence of malnutrition and malnutrition has decreased from $19.6 \%$ in 2013 to $17.7 \%$ in 2018 , with $3.9 \%$ malnourished toddlers and 13 malnourished toddlers. $8 \%$, if this happens for a long time, it will interfere with the growth in weight and height [2]. This short body size is a sign of prolonged malnutrition. Furthermore, malnutrition can affect children's brain development. Though the brain grows during toddlerhood. The fast-growing phase of the brain lasts from a fetus at 30 weeks of age to a baby at 18 months [3].

One indicator of the success of health development which is also part of national development is the good nutritional status of children under five. Toddlers are a target group that really needs special attention because of the negative impacts that may arise when suffering from malnutrition. Providing additional food, especially for vulnerable groups, is a supplementation strategy in overcoming nutritional problems. 
The Total Diet Survey (SDT) in 2014 revealed that more than half of toddlers $(55.7 \%)$ had an energy intake that was less than the recommended Energy Adequacy Rate (AKE). Providing additional food that focuses both on macro and micronutrients for toddlers is needed in the context of preventing stunting [4]. The supplementary food provided can be in the form of local food-based family meals with recommended recipes. Local food is more varied, but the cooking method and duration will greatly determine the availability of the nutrients contained in it. Local food ingredients that can be used as ingredients for making additional food include catfish, red beans, and Moringa leaves. Additional food that can be given besides biscuits, cookies is a snack bar.

Snack Bar is a solid food product that is classified as a semi-wet product or moisture food intermediate (IMF). The majority of existing snack bars are made from wheat flour and beans, therefore it is the biggest prospect in the Indonesian food industry if it develops snack bars made from local products, besides that it can also increase the economic value of local products, increase the diversification of locally processed food, and processed animal-based products as a source of protein in snack bars[5] .

Seeing the potential of snack bars in fulfilling nutrition, especially in reducing energy and protein deficiency (KEP), it is necessary to make a snack bar using local food such as catfish flour, red bean flour, and Moringa leaves flour.

\section{METHOD}

This study used a non-factorial Completely Randomized Design (CRD). The determination of the snack bar formulation was carried out in the Food Technology laboratory of the Nutrition Department of the Palembang Health Polytechnic. The making of the catfish flour uses the method used by Arza (2017)[6]. Red bean flour uses a process proposed by Pangastuti (2013)[7] and Moringa leaf flour uses the method from Kurniati (2018)[8].

Organoleptic tests were carried out in the sensory test laboratory of the Nutrition Department of the Health Polytechnic Ministry of Health Palembang using semitrained panelists. Determination of macronutrients using proximate and micronutrient tests (Fe, Folic Acid) and amino acids was carried out in the laboratory of PT Saraswanti Indo Genetech Bogor.

\section{RESULTS AND DISCUSSION}

\section{A. Organoleptic Test}

The Graph 1 shows that the type of formula most favored by the panelists from all aspects of the assessment is F2 with the use of 10 grams of catfish flour, 90 grams of red bean flour, and 3 grams of Moringa leaf flour. These results indicate that the more the use of red bean flour, the increased acceptance of the snack bar of catfish flour, red bean flour, and moringa leaf flour because the panelists generally like the taste of kidney beans.

The color produced on the snack bar treatment F1, F2, F3 has a dark brown color. Color can be caused by the caramelization process and the effect of drying carbohydrates (Martunis, 2012). The color equation occurs due to the roasting process. Naturally, the color is damaged by heating. Chemically, oxidation changes during storage. The result is processed food loses color and can reduce the sensory value (Adriani, et al, 2019).

The resulting organoleptic test results of the snack bar can be seen in Graph 1.

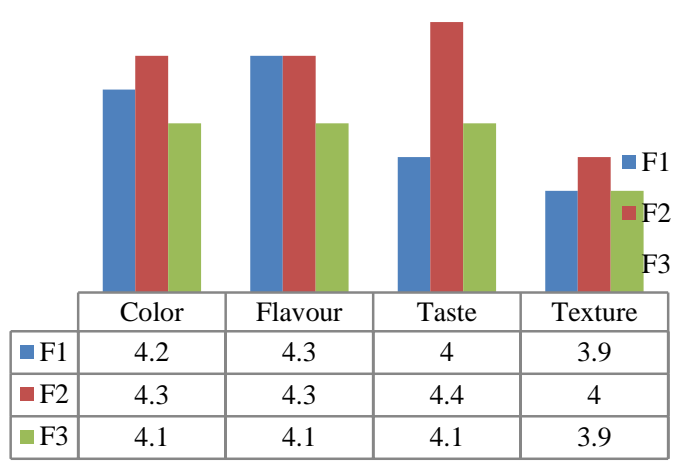

Graph 1. The average value of Organoleptic Test Results

The aroma is an odor that is difficult to measure so it usually leads to different opinions in assessing the quality of the aroma. Differences in opinion can be caused by each person having different smells, although they can distinguish between scents, everyone has different preferences [9]

The taste of food is an assessment factor for the results of combining the formulation of ingredients in making a food product that is assessed by the tongue, by measuring sweet, sour, salty, bitter, or other combinations, and is a determinant of the level of preference for food products. The taste of the three snack bar treatments was influenced by the use of basic 
ingredients, namely catfish flour, red bean flour, and Moringa leaf flour, and the use of milk and peanuts which made it slightly different from snack bars in general. The resulting solid food taste is sweet and savory. Sugar contributes to the sweetness and tenderness of the product [10].

Food texture is an assessment factor that is determined through the sense of touch and or by touch by measuring the hardness or consistency of food products. The texture is influenced by all the constituent ingredients which include peanuts, sugar, fat, milk, eggs [9;[11]. Food texture is determined by water content, fat content, carbohydrates, and protein [12]. The greater the protein content, the greater the water absorption. Red bean flour is a high source of protein which increases water absorption so that the resulting snack bar texture is stronger. Evidenced by the F2 snack bar, which has more red bean flour, the texture is a little tougher. The F1 snack bar with the same ratio of catfish flour and red bean flour produces a crunchy texture.

Each form of food has a different texture and depending on the physical condition, the texture assessment can be in the form of hardness, elasticity, or crunchiness [13]

\section{B. Nutrient Content}

The results of the study on the nutritional content of the snack bar of catfish meal, red bean flour, and Moringa leaf flour are as shown in table 1:

Table 1. The resulting Snack Bar Nutritional Content

\begin{tabular}{lc}
\hline \multicolumn{1}{c}{ Nutrients } & Total \\
\hline Energy (Kkal/100 gram) & 466,41 \\
\hline Protein (\%) & 17,2 \\
\hline Fat (\%) & 22,81 \\
\hline Carbohydrate $(\%)$ & 48,26 \\
\hline Iron (mg/100 gram) & 7,49 \\
\hline Vitamin C (mg/100 gram) & 1,61 \\
\hline
\end{tabular}

The results in Table 1 show that the resulting snack bar is high in energy and high in protein which of course this result will be very good for children with less nutritional status. When compared with the nutritional standard for Supplementary Food (PMT) for malnourished children, the resulting snack bar is close to the PMT standard as shown in Table 2.
Table 2. Comparison of Snack Bar Nutrition with PMT Standards for Undernourished Children

\begin{tabular}{lcc}
\hline \multicolumn{1}{c}{ Parameter } & Snack Bar & PMT \\
\hline $\begin{array}{l}\text { Energy (Kkal/100 } \\
\text { gram) }\end{array}$ & 466,41 & minimum 400 \\
\hline Protein (\%) & 17,2 & $8-12$ \\
\hline Fat (\%) & 22,81 & $10-18$ \\
\hline $\begin{array}{l}\text { Carbohydrates in } \\
\text { the form of fiber } \\
\text { gram) }\end{array}$ & 0,17 & maximum 5 \\
\hline $\begin{array}{l}\text { Iron (mg/100 } \\
\text { gram) }\end{array}$ & 7,49 & $4-7,5$ \\
\hline
\end{tabular}

The energy in the snack bar is almost the same as the PMT standard. The protein content contained in the Snack Bar was 17.2\%, higher than PMT. The high percentage of this protein is due to the use of fish and kidney beans and moringa which are rich in protein. Fat is also slightly higher than PMT standards, carbohydrates in the form of fiber and iron are in accordance with PMT standards[14]

\section{CONCLUSION}

The snack bar formula favored by panelists is a formula that uses a ratio of 10 grams of catfish, 90 grams of red bean flour, and 3 grams of Moringa flour. The resulting snack bar has nearly the same nutritional content as the standard for PMT.

\section{REFERENCES}

[1] Kemenkes, R.I., "Riskesdas 2013," 2013.

[2] R. I. Kemenkes, "HASIL UTAMA RISKESDAS 2018," p. 200, 2018.

[3] . Sarah E Cusick, Michael K, Georgieff, MD, "Opportunity of the 'First 1000 Days ,"' J Pediatr., vol. 175, pp. 16-21, 2017.

[4] Balitbangkes, SURVEI KONSUMSI MAKANAN INDIVIDU INDONESIA 2014 STUDI DIET TOTAL: 2014.

[5] E. P. da Silva, H. H. Siqueira, C. Damiani, and E. V. de B. Vilas Boas, "Physicochemical and sensory characteristics of snack bars added of jerivá flour (Syagrus romanzoffiana)," Food Sci. Technol., vol. 36, no. 3, pp. 421-425, 2016.

[6] M. T. Putri Aulia Arza, "Pengembangan Crackers dengan Penambahan Tepung Ikan Patin," vol. 40, no. 2, pp. 55-62, 2017.

[7] D. I. Hesti Ayuningtyas Pangastuti, Dian Rahmawanti Affandi, "Karakterisasi Sifat Fisik dan Kimia Tepung Kacang Merah (Phaseoulus vulgaris L.) dengan Beberapa Perlakuan Pendahuluan," J. Teknosains Pangan Vol 2 No 2 April 2013, vol. 1, no. 1, pp. 20-29, 2013.

[8] I. Kurniawati and M. Fitriyya, "Karakteristik Tepung Daun Kelor Dengan Metode Pengeringan Sinar Matahari," J. Gizi dan Pangan, vol. 1, pp. 238-243, 2018.

[9] A. Herawati, E.R.N., Miftakhussolikha, M., Pusporini, 
A.R., Murdiati, "Sensorial and chemical characterization of snack bar with variation of gembolo," vol. 3, no. October, pp. 564-569, 2019.

[10] N. A. Ladamay and S. S. Yuwono, "Pemanfaatan Pangan Lokal dalam Pembuatan Foodbars (Kajian Rasio Tapioka : Tepung Kacang Hijau dan Proporsi CMC)," J. Pangan dan Agroindustri, vol. 2, no. 1, pp. 67-78, 2014.

[11] R. Kasim, L. Ahmad, S. Une, Y. Bait, and S. A. Liputo, "Characterization of Snack Food Bars Made of Nixtamalized Corn Flour and Flour Of Nike Fish for Emergency Food," Int. J. Agric. Syst., vol. 5, no. 1, p. 33, 2017.

[12] J. D. P. C. Netto, P. R. C. de Oliveira Filho, J. LapaGuimarães, and E. M. M. Viegas, "Physicochemical and sensory characteristics of snack made with minced Nile tilapia," Food Sci. Technol., vol. 34, no. 3, pp. 591-596, 2014.

[13] G. H. Augustyn, H. Cynthia, D. Tuhumury, and M. Dahoklory, "Pengaruh Penambahan Tepung Daun Kelor (Moringa oliefera) terhadap Karkateristik Organoleptik dan Kimia Biskuit Mocaf ( Modified Cassava Flour )," vol. 6, no. 2, 2017.

[14] Kemenkes.R.I, "Peraturan Menteri Kesehata Republik Indonesia Nomor 51 Tahun 2016,” 2016. 